\title{
Neuropeptides and pain
}

\author{
Dimitra Molyva \\ From $1^{\text {st }}$ International Congress on Neurobiology and Clinical Psychopharmacology and European \\ Psychiatric Association Conference on Treatment Guidance \\ Thessaloniki, Greece. 19-22 November 2009
}

Neuropeptides comprise a diverse group of chemically distinct molecules, contained in and released from a range of sensory nerves. They are involved in the formation, transmission, modulation and perception of all types of pain (physiological, neuropathic and inflammatory). This fact is reflected on their wide distribution, from primary sensory neurons to the dorsal root ganglia of the spinal cord and the brain. With the recent advent of molecular cloning techniques, transgenic animal models and the development of non peptide agonists/antagonists, efforts to describe their roles in the nociceptive processes at the molecular level have revealed a complicated pattern in terms of their localization, function and receptor expression. They co-localize with other neuropeptides or with neurotransmitters (ie. GABA) within the same nerve-ending; when released, they either block or enhance the effect of these other neurotransmitters and/or neuropeptides. In addition, neuropeptides, such as calcitonin-gene-related peptide (CGRP) and neuropeptide tyrosine (NPY), have been found to be expressed and released from non-neuronal cells, acting via the same (or more distant) receptors as their neuronal counterparts. Peptide expression is also characterized by plasticity under normal and experimental conditions, a trait related to their pleiotropic function. On the other hand, it is probable that neuropeptide action is characterized by considerable redundancy, which may account for the poor performance of individual neuropeptide inhibitors in clinical trials. This situation may well change however, as more and more neuropeptide targets are being characterized and techniques for the specific ablation of entire neuropeptide-synthesizing neurones are being developed. Hopefully, novel pain treatments based on the targeting of neuropeptide action are going to replace - or, at least, complement - the current use of opiate drugs, leading to increased efficacy and reduced adverse effects, in the not-too-distant future.

\footnotetext{
1st Department of Pharmacology, School of Medicine, Aristotle University of Thessaloniki, Greece
}

Published: 22 April 2010

doi:10.1186/1744-859X-9-S1-S3

Cite this article as: Molyva: Neuropeptides and pain. Annals of General Psychiatry 2010 9(Suppl 1):S3.

Submit your next manuscript to BioMed Central and take full advantage of:

- Convenient online submission

- Thorough peer review

- No space constraints or color figure charges

- Immediate publication on acceptance

- Inclusion in PubMed, CAS, Scopus and Google Scholar

- Research which is freely available for redistribution

Submit your manuscript at www.biomedcentral.com/submit 